\title{
Relationship between Earnings Management and Earnings quality in the Globalized Business Environment
}

\author{
Juraj Cug*, and Aneta Cugova ${ }^{1}$ \\ ${ }^{1}$ University of Zilina, Faculty of Operation and Economics of Transport and Communication, Department of Economics, Univerzitna \\ 8215/1, 01026 Zilina, Slovak Republic
}

\begin{abstract}
.
Research background: Earnings management is a versatile phenomenon in firms' financial reporting and It's purpose is to demonstrate reasonable earnings quality. Thus, earnings management has much in common with earnings quality.

Purpose of the article: This paper reviews earnings management and earnings quality in an information economics framework. We focus on earnings quality determinants, impact of earnings quality and the outcomes of earnings quality for companies.

Methods: Basic scientific methods of analysis, synthesis, induction, deduction and abstraction were used to meet the stated goal.

Findings \& Value added: In general, earnings of high quality are those that have a high level of persistence, are more predictable, more timely, less volatile and have lower level of earnings management. Earnings management has a negative impact on the quality of earnings if it distorts the information in a way that is less useful for forecasting future cash flows.
\end{abstract}

Keywords: Earnings management; Account Management; Earnings quality

JEL Classification: $M 41 ; G 12 ; G 14$

* Corresponding author: juraj.cug@,fpedas.uniza.sk 


\section{Introduction}

The most frequently used term of manager intervention in accounting information in the empirical literature is earnings management. Often is used term cosmetic accounting or accounting manipulation. Schipper characterizes earnings management as a manager intervention in external financial reporting process to appropriate personal gain. [1]

This definition shows that earnings management results in managers' opportunistic behavior. Earnings management is a managerial practice that is a result of researches in positive accounting theory and agency theory and has emerged in the context of information asymmetry between managers and other business partners. Earnings management can be also examined in the context of efficient market theory. In this perspective managers are motivated to manipulate earnings to show more informative disclosure. [2]

Earnings management is a global phenomenon in financial reporting. The purpose of earnings management is to demonstrate reasonable earnings quality that meets the shareholders' expectations and the requirement of obtaining relevant authorization from regulators. It has much in common with earnings quality, earnings persistence, predictability, and earnings smoothness in the financial health assessment of a company.

Quality of Earnings represents a real picture of the company without any anomalies or accounting tricks. Ii offers a close examination of company finances. It refers to the income of the company generated from the main operations. Often it is seen that net income doesn't represent the true financial picture of a company. It may happen that a company reports a massive net income, but the operating cash flows are negative. In that case, one can't say that the company is financially sound. To get the true position in these cases, it is necessary to calculate the quality of earnings.

Earnings management is closely connected to earnings quality. Usually every managed earnings have low quality. It doesn't mean, that the lack of earnings management is sufficient to ensure high earnings or accounting numbers quality. There is so many other factors contribute to the quality of earnings. [3, 4]

The quality of earnings is a very important determinant that significantly influences the decision made by a shareholder in the company. The quality of earnings is closely related to the persistence of earnings. Persistent earnings can reflect the sustainability of earnings in the future that is determined by accrual components and the cash flows. Earnings persistence presents an earnings audit that is expected in the future reflected from running year earnings. It means, earnings persistence can be used as future earnings marker. Sustainable earnings persistence are earnings that have very high quality; in the contrary, if unusual earnings are stated as earnings that have lean quality. [5] According Ball and Shivakumar high quality earnings are conservative, while low quality earnings are upwardly managed earnings. [6]

There is also connection between earnings persistence and their informativeness. More persistent earnings show more informative earnings and contrariwise, if earnings are less persistent, earnings are less informative. Earnings persistence can be used to measure earnings quality by the slope coefficient of current earnings regression on lagged earnings. [7]

\section{Methodology and data}

Our approach to study earnings management and earnings quality is based on the information economics literature. We discuss a variety of theoretical models that capture the effects and interactions of managers' incentives and rational expectations of users. There are several surveys that discuss earnings quality in connection with earnings management. Some authors provide a detailed analysis of earnings management from both an analytical and empirical perspective. [8]. Beyer et al. analyze mandatory and voluntary disclosure extensively. [9] Kanodia focuses on examination of real effects of earnings management on accounting reports. [10] Others survey earnings quality mainly from an empirical perspective. [11, 12]

Regarding earnings quality and earnings management, a variety of studies have been conducted, and each of these studies addressed the issue of the specific dimension. [13 - 16]

\section{Results}

There are multiple benchmarked and views used to measure the earnings quality and also many attributes can be used to measure its outcomes. Both the determinants and consequences can be used to estimate the quality of earnings. Earnings quality proxies keep unique features: special combination of quality determinants and consequences. [17]

Based on the accounting research literature, proxies of earnings quality might include the following:

- properties of earnings:

$\circ$ earnings persistence and smoothness,

- TLR - timely loss recognition,

o accounting conservatism,

- predictive ability,

○ magnitude of accruals, 
goals meeting, etc.

- investor's response to earnings: auditor quality, accounting methods,

- $\quad$ external indicators of misstatements: restatements, weaknesses in internal control.

One of the external indicators of earnings quality is restatements of financial statements. The determinants of restatements include, to name a few, audit committees with financial expertise and executive compensation portfolios that are sensitive to stock price. Restatements can affect consequences, company value, company management for example turnover and company litigation risk.

\subsection{Earnings quality determinants}

The determinants of earnings quality might include:

- company characteristics: performance, size, growth, investment, debt,

- company financial reporting practices: financial statement classification, interim reporting, accounting methods used,

- company governance and internal controls: characteristics of the Board of Directors, managerial ownership, compensation,

- audit: auditor industry expertise, hours spent auditing,

- external factors: politics, tax regulation, capital requirements,

- capital market incentives: earnings-based targets, raising capital, etc.

Firm characteristics are closely associated with the proxies for earnings quality. Company that are performing poorly engage in accounting tactics to improve the earnings. In general, weak company performance provides incentives to engage in earnings management. Debt levels are associated with various measures of earnings quality. Relation between size and earnings quality differ across measures. Some authors predict that company size is negatively associated with earnings quality because bigger firms select income-decreasing accounting methods in response to greater regulatory scrutiny. Others consider size is positively associated with quality of earnings because of fixed costs connected with maintaining adequate internal control. [18]

Regarding financial reporting practices, many researches have examined the effects of financial statement classification and interim reporting on earnings quality. Companies use discretion over income statement classification within a period to shift expenses into categories that are perceived as less persistent to meet analyst forecasts.

Internal controls include monitoring mechanisms, chosen by the principal in the principal-agent relationship, as well as bonding mechanisms, chosen by the agent at some cost. The mechanisms include characteristics of the Board of Directors (BOD), internal control procedures and managerial share ownership, etc. [19]

Auditors are a determinant of earnings quality because of their role in reduction intentional and unintentional misstatements. The ability of an auditor is to detect a material misstatement and adjust for or report it.

\subsection{Impact of earnings quality}

Earnings quality is an important determinant to minimize information asymmetry and thus promote the development of financial markets. It can be viewed as the potential profitability or the possibility to achieve the expected profit growth in the future.

Earnings are closely monitored by financial market participants, investors and analysts. Reported profits are a leading source of specific information for companies, as they are a good indicator of future cash flows and there is more information about a company's economic performance than cash.

The quality of earnings affects:

- analyst forecasts,

- audit opinion,

- executive compensation and labor market,

- firm cost of debt and equity capital,

- firm real activities,

- litigation risk,

- market valuation.

\subsection{The outcomes of earnings quality for companies}

Generally applicable, higher quality of earnings often support to receive higher stock prices, higher credit limits, lower interest rates, etc.

The quality of earnings is very important to users of financial information, as well as to regulators, accounting researchers and practitioners. Because there are so many dimensions of earnings quality, market participants use various factors to estimate this quality. Analysts usually consider the following factors when evaluating the quality of earnings:

- earnings characteristics: earnings trend, major source of net income, conversion of sales into cash 
- firm characteristics: market share, brand awareness and loyalty, labor relations

financial ratios: debt-to-equity, total liabilities to total assets, rate of return on investment, earnings per share, priceearnings ratio, dividend payout ratio, net profit as a percentage of sales, percentage of expenses to sales, sales growth rate, etc.

- audit opinion.

Earnings quality can be viewed from such perspectives as:

- $\quad$ analyst expertise,

- auditor independence,

- decision usefulness,

- balance sheet,

- $\quad$ earnings management,

- financial analysis/reporting,

- measurement,

- international.

In terms of decision usefulness, the quality of earnings means how precisely the earnings reflect the changes in the wealth of a company. In terms of financial analysis, the earnings quality means how precisely the earnings measure the value of the company and how exactly the earnings represent the firm's current and future performance.

The earnings quality presents the proportion of income attributable to the business core operating activities. If the company shows an increase in profits due to improved sales or reduction of cost, the quality of earnings is considered high. On the contrary, the company can have low-quality earnings if changes in its earnings relate to other issues, such as:

- $\quad$ aggressive use of accounting rules,

- $\quad$ elimination of LIFO inventory layers,

- inflation,

- $\quad$ sale of assets for a gain,

- $\quad$ increases in business risk.

In general, any use of accounting fraud to temporarily increase earnings reduces their quality.

High-quality earnings are readily repeatable over a series of reporting periods, rather than being earnings that are only reported as the result of a one-time event. In addition, the company should routinely provide detailed reports regarding the sources of its earnings, and every future changes of these sources. Very important is that the reporting company engages in conservative accounting practices, so that all relevant expenses are duly recognized in the correct period, and revenues are not artificially increased.

\section{Discussion}

Quality of earnings is Revenue Minus Expenses, modified for One-Time Cost

It is important to understand that quality of earnings begin with quality of revenue. Many businesses do not manage well their revenue quality metrics. There are many instances when we encounter poor revenue recognition methodologies. If the company do not have a bad debt reserve, yet they experience occasional write-offs or issue credits, earnings and revenue are overstated by the same amount. The next problem can by bad well-developed revenue waterfall reports. While It's not a component of a quality of earnings report, the better documented and predictable revenue flow, the more probable it is that positive changes to your quality of earnings will be. Next key factor is consistency and predictability of revenue. The more consistence and predictable revenue are the value is higher. Whereas volatility and unpredictability in revenue reduce their value.

Quality of earnings starts with quality of revenue

For any adjustment to revenue/expenses to truly qualify as something that improves quality of earnings, it must have credible sustainability. Many times we see "one-time" expenses adjusted out that occur every year; It will be difficult for an investor to believe that spending cuts will be sustainable in the future.

Conversely, adding back excess compensation where the new compensation level is documented in an employment agreement is perfectly acceptable.

Another point to consider is whether the expenses are related revenue. Investors want to know how much did it cost to generate the revenue and they are interested in ensuring that all of the costs are included, because they want to be comfortable that the company can continue to generate the same revenue without incurring more costs.

Understanding of Earnings Quality helps for discussions with investors, lenders and/or buyers

Sometimes there are situations in which the quality of earnings is being evaluated by third parties for some kind of transaction. If company consider a sale of the business, it naturally wants to reach the highest possible level of earnings, because most valuations are based on the earnings stream.

However, if shown earnings include adjustments attributable to changes in accounting method or policies, recent expense reductions or price increases, cost savings from short-term commodity price fluctuations or some other similar factors, then the company may not receive full value consideration. 
The perception of adjustments is important. For example, if a significant adjustment is for recent cost savings, it could cause an investor to think why the management team hasn't been operating the business as efficiently as possible all time along.

\section{Conclusion}

The quality of earnings is difficult to define and there are no exact criteria by which to measure it. There are so many factors that can be considered in assessing the quality of earnings. But in general, the quality of earnings can be characterized as the degree to which earnings are cash or noncash, recurring or nonrecurring. They based on precise measurement or estimates that are subject to change. Evaluating the quality of earnings will help the financial statement user make decisions about the certainty of current income and the expectation for the future. Regarding earnings quality, it is important to understand that lower quality earnings are not indicators of poor financial situation or the misapplication of accounting policies, estimates and judgments. The lower quality earnings items often relate to transactions that by their nature are more subjective, riskier or uncertainty. In addition, accounting standards by design are flexible so they can be applied across many marketplaces, industries, geographies and differing circumstances.

This research was financially supported by the Ministry of Education, Science, Research and Sport of the Slovak Republic and Slovak Academy of Sciences VEGA 1/0121/20: Research of transfer pricing system as a tool to measure the performance of national and multinational companies in the context of earnings management in conditions of the Slovak Republic and V4 countries.

\section{References}

1. Schipper, K. (1989). Commentary on Earnings Management. Accounting Horizons, 3(4, 5), 91-102.

2. Watts, R., Zimmerman, J. (1986). Positive Accounting Theory, Prentice Hall.

3. Khuong, N.V., Liem, N.T., Minh, M.T.H. (2020). Earnings management and cash holdings: Evidence from energy firms in Vietnam. Journal of international studies, 13(1).

4. Khanh, M.T.H., Thu, P.A. (2019). The effect of financial leverage on real and accrual-based earnings management in Vietnamese firms. Economics and Sociology, 12(4), 299-312.

5. Penman, S.H., Zhang, X.J. (2002). Accounting conservatism, the quality of earnings, and stock returns. Accounting Review, 77(2), 237-264.

6. Ball, R., Shivakumar, L. (2008). Earnings quality at initial public offerings. Journal of Accounting and Economics, $45(2-3), 324-349$.

7. Tucker, J.W., Zarowin, P.A. (2006). Does income smoothing improve earnings informativeness? Accounting Review, 81(1), 251-270.

8. Ronen, J., Yaari, V. (2008). Earnings Management. New York, NY.

9. Beyer, A. (2009). Capital market prices, management forecasts, and earnings management. Accounting Review, 84(6), 1713-1747.

10. Kanodia, C. (2006). Accounting disclosure and real effects. Foundations and Trends in Accounting, 1(3), 1-95.

11. Francis, J., Olsson, P., Schipper, K. (2006). Earnings quality. Foundations and Trends in Accounting, 1(4), 259340.

12. Dechow, P.M., Ge, W., Schrand, C. (2010). Understanding earnings quality: a review of the proxies, their determinants and theirconsequences. Journal of Accounting and Economics, 50, 344-401.

13. Siekelova, A., Podhorska, I. (2020). Earnings Indicators under the Condition of Globalization. SHS Web of Conferences, 74, 01031.

14. Durana, P., Valaskova, K., Chlebikova, D., Krastev, V., Atanasova, I. (2020). Heads and Tails of Earnings Management: Quantitative Analysis in Emerging Countries. Risks, 8(2), 57.

15. Kliestik, T., Valaskova, K., Nica, E., Kovacova, M., Lazaroiu, G. (2020). Advanced methods of earnings management: monotonic trends and change-points under spotlight in the Visegrad countries. Oeconomia Copernicana, 11(2), 371-400.

16. Fischer, P.E., Stocken, P.C. (2004). Effect of investor speculation on earnings management. Journal of Accounting Research, 42, 843-870.

17. Svabova, L., Valaskova, K., Durana, P., Kliestik, T. (2020). Dependency Analysis Between Various Profit Measures and Corporate Total Assets for Visegrad Group's Business Entities. Organizacija, 53(1), 80-90.

18. Siekelova, A., Androniceanu. A., Durana P., Frajtova Michalikova. K. (2020). Earnings management (EM), initiatives and company size: An empirical study. Acta Polytechnica Hungarica, 17(9), 41-56 
19. Pisar, P., Bilkova, D. (2019). Controlling as a tool for SME management with an emphasis on innovations in the context of Industry 4.0. Equilibrium - Quarterly Journal of Economics and Economic Policy, 14(4), 763-785. 